Atıf İçin: Ağırağaç Z, Çelebi Ş Z, 2021. Kentsel Atık Suların Karamba (Lolium multiflorum cv. Caramba)'nın Ağır Metal ve Bazı Besin Elementi İçeriğine Etkisi. Iğdır Üniversitesi Fen Bilimleri Enstitüsü Dergisi, 11(3): 2400-2411.

To Cite: Ağırağaç Z, Çelebi Ş Z, 2021. The Effect of Urban Waste Waters on Heavy Metals and on Some Nutrient Contents of the Caramba Plant (Lolium multiflorum cv. Caramba). Journal of the Institute of Science and Technology, 11(3): 2400-2411.

\title{
Kentsel Atık Suların Karamba (Lolium multiflorum cv. Caramba)'nın Ağır Metal ve Bazı Besin Elementi İçeriğine Etkisi
}

\section{Zübeyir AĞIRAĞAÇ${ }^{1}$, Şeyda ZORER ÇELEBI ${ }^{1 *}$}

ÖZET: Bu araştırmada, Van/Edremit İleri Biyolojik Atıksu Arıtma Tesisi çıkış suyunun farklı konsantrasyonlarda Karamba bitkisinin gelişimi ile uygulamalar sonrası bitki ve toprağın bazı besin elementi içeriklerine etkisi araştırıldı. Deneme 2018 yılında Van Yüzüncü Yıl Üniversitesi Ziraat Fakültesi Tarla Bitkileri Bölümü iklim odasında saksılarda; tesadüf parselleri deneme desenine göre üç tekrarlamalı olarak yürütüldü. Araştırmada atık suların Karamba bitkisinin gelişimine etkisini belirlemek için kontrol olarak \% 100 saf su (100S), \%75 saf su + \%25 atıksu (75S25A), \%50 atık su + $\% 50$ saf su (50S50A) ve \%25 saf su + \%75 atık su (25S75A) şeklinde uygulama yapıldı. Çalışma sonuçlarına göre, Van İli atık su konsantrasyonlarının Karamba'nın çıkışı ve ortamdan çekilmesi üzerine önemli bir etkisi bulunmadı, bitki boyu, yaş ve kuru ot miktarlarını arttırdığı saptandı. Bitki ve hasat sonrası toprakta element konsantrasyonları genel olarak arttığı belirlendi. Hasat sonrası toprakta pH düştü ancak EC değerinde artış belirlendi. Araştırma sonucunda, Van/Edremit İleri Biyolojik Atıksu Arıtma Tesisi suyunun kısa süreli bitki yetiştiriciliğinde kullanılabileceği, ancak uzun süreli kullanımının belirlenmesi için farklı bitki gruplarıyla daha uzun süreli çalışmalara ihtiyaç olduğu düşünülmektedir.

Anahtar Kelimeler: Atık su, bitki gelişimi, element konsantrasyonu, Karamba.

\section{The Effect of Urban Waste Waters on Heavy Metals and on Some Nutrient Contents of the Caramba Plant (Lolium multiflorum cv. Caramba)}

\begin{abstract}
In this study, the effects of different concentrations of the outflow water of Van/Edremit Advanced Biological Waste-Water Treatment Plant on the growth of Caramba plant and on some nutrient contents of plant and soil after the application are investigated. The experiment was carried out with three replications in the pots according to the experimental design of random plots in the climate chamber of the Department of Field Crops, Faculty of Agriculture, Van Yüzüncü Y1l University in 2018. In order to determine the effect of wastewater on the development of Caramba plant, $100 \%$ pure water (control) $(100 \mathrm{~S}), 75 \%$ pure water $+25 \%$ waste water $(75 \mathrm{~S} 25 \mathrm{~A}), 50 \%$ waste water $+50 \%$ pure water $(50 \mathrm{~S} 50 \mathrm{~A})$ and $25 \%$ pure water $+75 \%$ waste water $(25 \mathrm{~S} 75 \mathrm{~A})$ were applied. According to the results of the study, the waste water concentrations of Van province did not have any effect on the germination and decreasers of Caramba, and it was determined that the waste water concentrations increase plant height, green and dry grass amount. It has been determined that the element concentrations in plant and in soil after harvest increase in general. The decrease in $\mathrm{pH}$ value was observed in post-harvest soil, while the increase in EC value was determined. As a result of the research, it is thought that Van/Edremit Advanced Biological Waste-Water Treatment Plant water can be used in short-term plant growing but longterm studies with different plant groups are needed to determine its long-term use.
\end{abstract}

Keywords: Waste water, plant growth, element concentration, Caramba.

1'Zübeyir AĞIRAĞAÇ (Orcid ID: 0000-0003-1414-1472), Şeyda ZORER ÇELEBİ (Orcid ID: 0000-0003-1278-1994), Van Yüzüncü Yıl Üniversitesi, Ziraat Fakültesi, Tarla Bitkileri Bölümü, Van, Türkiye

*Sorumlu Yazar/Corresponding Author: Şeyda ZORER ÇELEBİ, e-mail: seydazorer@yyu.edu.tr 


\section{GİRİ̧}

Su canlı yaşamının devamı için vazgeçilmez olduğundan artan nüfusla birlikte suya ihtiyaçta gün geçtikçe artmaktadır. Yetersiz su kaynakları ve kaynakların kalitesinin bozulması dünyada kaygıyla karşılanmakta ve bu durumun geleceğin başlıca sorunu olacağı tartışılmaktadır (Polat, 2013). Nüfusun hızla artmasına paralel olarak beslenme ihtiyacını karşılamak için tarımsal suya ihtiyaç da giderek artmaktadır. Türkiye'nin yüzölçümü 78 milyon hektar $\left(783.577 \mathrm{~km}^{2}\right)$ olup, tarım arazileri bu alanın yaklaşık üçte biri yani 28 milyon hektar civarındadır. Yapılan analizlere bakıldığında ekonomik olarak sulanabilecek 8.5 milyon hektar alanın 2017 yılı sonu itibari ile toplam 6.5 milyon hektarı sulamaya açıldığ Köy Hizmetleri Genel Müdürlüğü (KHGM) ve İl Özel İdareleri tarafından kullanıma açılmıştır. Yaklaşık 1 milyon hektar alanda ise halk sulaması yapılmaktadır. 2023 yılında ekonomik olarak sulanabilir 8.5 milyon hektar arazinin bugün itibarıla sulanmayan 2 milyon hektarlık bölümünün de DSİ Genel Müdürlüğü tarafından işletmeye açılması amaçlanmıştır (DSİ, 2018). Giderek artan su ihtiyacı nedeni ile tarımsal sulama ihtiyacının karşılanması için alternatif su kaynaklarının değerlendirilmesi oldukça önemlidir. Özellikle arıtılmış atık suların kullanılabilir kaliteye getirildikten sonra tarımsal alanlarda kullanılması su kaynağı ihtiyacını ortadan kaldırmak için önemli bir alternatif olacaktır. Kentsel atık suların suda çözünmüş veya asılı halde inorganik ve organik madde içeriği suya oranla çok daha düşük konsantrasyonlardadır. Atık su içeriğinde bulunan organik maddeleri proteinler, deterjanlar, sabun, karbonhidratlar, lignin, yağlar, sentetik deterjanlar ve bunların ayrışmasından meydana gelen ürünler ile çeşitli doğal ve sentetik organik kimyasallar yer almaktadır. Kentsel atık suların bünyesinde evsel ve endüstriyel kaynaklı inorganik maddelerde bulunmaktadır. Evsel ve endüstriyel atık sular kıyaslandığında özellikle endüstriyel atık sular çinko $(\mathrm{Zn})$, bakır $(\mathrm{Cu})$, arsenik (As), krom (Cr), civa ( $\mathrm{Hg})$ gibi toksik etkiye sahip elementler içerirler. Bu elementler insan sağlığı üzerinde toksik değerlere ulaşmasa bile bitki üzerinde toksik etkiye neden olabilirler. İnsan sağlı̆g açısından atık suların en büyük risklerinden biri patojenlerdir (Pescod, 1992). Türkiye'de 14.6 milyon hektar çayır, mera arazisi bulunmakta ve bu oran ülke alanının yaklaşık \%18.7'lik bir kısmını oluşturmaktadır (TÜIKK, 2019). Ancak çayır ve meralarımız, aşırı ve erken otlatma, geç otlatma ve bakım işlerinin yapılamaması nedeni ile önemli ölçüde tahrip olmuştur. Mevcut hayvan varlığımızın kaba yem ihtiyacını karşılamak için yem bitkileri ekim alanlarının ve verimlerinin arttırılması zorunluluk haline gelmiştir (Yolcu ve Tan, 2008). Yem bitkileri hayvan varlığımızın kaba yem ihtiyacını karşılamada, önemli bir role sahip olup sürdürülebilir kaba yem üretiminin olmazsa olmazıdır. Tarımsal faaliyetler içerisinde çok önemli bir yere sahip olan yem bitkileri tarımı, bitkisel ve hayvansal üretimin sigortası konumundadır. Tarım arazilerinde üretilen yem bitkileri öncelikle hayvanlar tarafından kullanılmakta et, süt vb. ürünlere dönüştürülerek bu ürünlerden insanlar yararlanmaktadır (Soya ve ark., 2004). Yem bitkileri, ucuz bir kaynak olması, hayvanların mide mikro florası için gerekli besin maddelerini içermesi, mineral ve vitaminlerce zengin olması, hayvanların üreme gücünü artırması ve yüksek kalitede hayvansal ürün sağlaması bakımından hayvan beslemede önemlidir (Serin ve Tan, 2001). Yem bitkileri üretimimiz, ülkemiz hayvan popülasyonunu yeterince beslemeye yönelik nitelik ve nicelikte değildir. Günümüzde kaliteli, ucuz ve bol kaba yem kaynağ olarak kullanılabilecek yüksek verimli kültür yem bitkileri geliştirilmiştir. Bunlardan biri, İtalyan çimi (Lolium multiflorium)'nin bir varyetesi olan Karamba (Lolium multiflorium cv. caramba )' dir. Gelişmiş ülkelerde hayvancılıkta yaygın şekilde kaba yem olarak kullanılan Karamba yem bitkisi geniş yapraklı, çok lezzetli, kuru madde, protein, kolay çözünebilir karbonhidratlar, mineral maddeler bakımından zengin olması ve biçim zamanına kadar bitki gövdesinin çabuk kabalaşmayıp taze kalması 
gibi özellikleri nedeniyle ülkemizdeki hayvancılığının kaba yem sorununu çözmede yardımcı olabileceği belirlenmiştir (Lenuweit ve Gharadjedaghi, 2002; Kuşvuran ve Tansı, 2005; Özkul ve ark., 2012). İtalyan çiminin bir çeşidi olan halk dilinde "süt otu” olarak bilinen Karamba bitkisi Türkiye toprak ve iklim koşullarına iyi adaptasyon sağlayan tek yıllık bir yem bitkisidir. Süt otu orta kaliteli mera bitkilerine kıyasla HP, kolay fermente olabilen karbonhidrat ve mineral açısından daha zengin bir yap1 gösterir. Lezzetli, sindirilebilir oranı yüksek ve fazla miktarda ME (Metabolize olabilir enerji değeri) içeriğine sahip olup, yılda birden fazla biçim özelliğine sahiptir (Kesiktaş, 2010; Baldinger ve ark., 2011). Ruminant hayvan beslemede otlatılarak ya da biçimi yapılarak taze kullanılabildiği gibi, silaj1 yapılarak veya kurutularak da kullanılabileceği belirtilmektedir (Bernard ve ark., 2002; Cooke ve ark., 2008; Gemalmaz ve Talay, 2016; Çetinkaya, 2019). Yapılan araştırmalarda İtalyan çimlerinin yüksek oranda (\% 71-78) kuru madde (KM) sindirilebilir özelliğine sahip olduğu (Catanese ve ark., 2009; Amaral ve ark., 2011), süt bileşimini ve verimini olumlu yönde etkilediği (Mccormick ve ark., 1990; Maccormick ve ark., 1998; Miller ve ark., 2001), çiftlik hayvanlarının canlı ağırlık artışında etkili olduğu (Zaman ve ark., 2002; Van Niekerk ve ark.,2008) belirtilmektedir.

$\mathrm{Bu}$ çalışmanın amacı hızlı büyüme ve gelişme özelliğine sahip Karamba (süt otu) bitkisinin Van ili kentsel atık suları ile yetiştirme potansiyelini belirlemek ve bitkideki besin elementi ve ağır metal birikimini ve topraktaki bazı değişimleri tespit etmektedir.

\section{MATERYAL VE METOT}

Araştırma Van Yüzüncü Yıl Üniversitesi Ziraat Fakültesi Tarla Bitkileri Bölümü iklim odasında yürütüldü. Denemede bitki materyali olarak Lolium multiflolorum cv. Caramba, sulama materyali olarak Van İli Edremit İlçesi İleri Biyolojik Arıtma Tesisi çıkış noktasından alınan atık su kullanıldı. Denemede kullanılan toprak örnekleri Van Yüzüncü Yıl Üniversitesi Kampüs alanında bulunan deneme alanından 0-30 cm derinlikten alınarak önce kurutulmuş daha sonra elekten geçirilerek bir kısmı deneme saksılarına dolduruldu geri kalan kısmı da analizler için saklandı. Toprak örneklerindeki kum, kil ve silt (\%) fraksiyonları hidrometrik yöntemle belirlendi ve tekstür üçgeni yardımı ile tekstür sınıfına ulaşıldı (Bouyoucos, 1951). Denemede kullanılan atık su Edremit/Van İleri Biyolojik Atıksu Arıtma tesisi çıkış suyundan her sulama için ayrı ayrı alındı. Aynı gün plastik bidon içerisine alınan atık su iklim odasına getirilerek sulama suyu olarak kullanıldı. Edremit/Van İleri Biyolojik Atıksu Arıtma Tesisi, toplam $2477212 \mathrm{~m}^{2}$ saha üzerine kurulmuş olup, Tesis çıkış suyu kalitesi Avrupa Birliği Standartları'na uygundur. Tesisten çıkan arıtılmış su Van Gölü'ne verilmektedir (VASKİ, 2018). Denemede sulama suyu olarak kullanılan arıtma tesisi çıkış suyunda ve denemede kullanılan hasat öncesi ve hasat sonrası toprakta reaksiyon (Mclean, 1982), elektriksel iletkenlik (EC) (Richards, 1954) ile topraktaki organik madde (Nelson ve Sommer, 1982), mikrodalga parçalama yöntemi (Advanced Microwave Digestion System, Ethos Easy) ile Kacar ve İnal (2008)'ın bildirdiği şekilde, yaş yakma sonucu elde edilen numunede alüminyum (Al), bor (B) ve molibden (Mo) konsantrasyonları indüktif olarak eşleştirilmiş plazma- kütle spektrometresi (ICP-MS) ve demir (Fe), bakır $(\mathrm{Cu})$, çinko $(\mathrm{Zn})$, mangan $(\mathrm{Mn})$, kobalt $(\mathrm{Co})$, nikel $(\mathrm{Ni})$, berilyum $(\mathrm{Be})$, selenyum $(\mathrm{Se})$, vanadyum $(\mathrm{V})$, arsenik $(\mathrm{As})$, kurşun $(\mathrm{Pb})$, kadmiyum $(\mathrm{Cd})$ ve krom $(\mathrm{Cr})$ konsantrasyonları indüktif eşleşmiş plazma-optik emisyon spektrometresi (ICP-OES) ile Van Yüzüncü Y1l Üniversitesi Bilim Uygulama ve Araştırma Merkezi'nde belirlendi ve atık suya ait sonuçlar Tablo 1'de verildi.

Deneme 2018 yılında Yüzüncü Y1l Üniversitesi Ziraat Fakültesi Tarla Bitkileri Bölümü iklim odasında; tesadüf parselleri deneme desenine göre yüksekliği $22.5 \mathrm{~cm}$, taban çap1 $7.5 \mathrm{~cm}$ ve üst çap1 10 cm olan saksılarda üç tekrarlamalı olarak yürütüldü. Araştırmada kentsel atık suların Karamba bitkisinin gelişimine etkisini belirlemek için kontrol olarak \% 100 saf su (100S), \%75 saf su $+\% 25$ 
atık su (75S25A), \%50 atık su + \%50 saf su (50S50A) ve \%25 saf su + \%75 atık su (25S75A) şeklinde uygulama yapıldı. Ekimden önce temel gübreleme olarak, bütün saksılara hacim hesabı ile azot $(\mathrm{N})$, fosfor (P) ve potasyum (K) uygulandı (Kacar ve İnal, 2008). Her bir saksıya 15 adet tohum gelecek şekilde ekim yapıldı ve 29 gün sonra her saksıda 10 bitki olacak şekilde seyreltme işlemi ve ilk biçim yapıldı. Çalışma süresi boyunca 8 gün ara ile ortamdan çekilme takibi ve belirlenen kurallar çerçevesinde sulama yapıldı ve 20 gün ara ile biçim gerçekleştirildi. Karamba uygun hava koşullarında 20 günde bir biçime gelmektedir (Anonim 2018). Her biçimden elde edilen bitki materyali paketlenerek bekletildi ve deneme sonunda paçal yapılarak element analizine tabi tutuldu. Deneme 6 ay devam etti ve deneme süresince her bir saksıda bulunan bitkilerden biçim öncesi rastgele seçilen beş bitkinin boyları cetvel yardımıyla cm olarak ölçülerek ortalaması alınıp kaydedildi. Bitkiler biçim yüksekliği otlatma kriteri baz alınarak toprak yüzeyinden $3 \mathrm{~cm}$ yükseklikten makas yardımıyla kesilerek ayrı ayrı hassas terazide tartılıp yaş ağırlığı kaydedildi ve bitkiler ayrı ayrı kese kağıtlarına koyulup etiketlendi ve $70{ }^{0} \mathrm{C}$ 'de etüvde sabit ağırlı̆̆a gelinceye kadar kurutulup hassas terazide tartılarak kaydedildi. İstatistiksel analizler, IBM SPSS Statistics, Version 22.0 yazılımı (IBM Corp.) kullanılarak gerçekleştirildi. Çıkış, bitki boyu, yaş ot verimi ve kuru ot verimine ait değerler her biçimde ayrı ayrı analize tabi tutuldu. Bitki materyalindeki element ve hasat sonrası topraktaki element konsantrasyonlarına ait değerlerde ayrı ayrı istatistiki analiz yapıldı. İstatistiki analiz olarak ANOVA ve ortalamalar arasındaki farklar Duncan testi kullanılarak belirlendi.

Tablo 1. Denemede kullanılan atık suyun bazı özellikleri

\begin{tabular}{lll}
\hline Özellikler & Miktarlar & Sinır Değerler* \\
\hline $\mathrm{pH}$ & 7.81 & $6.5-9$ \\
$\mathrm{EC}\left(\mu \mathrm{mhos} \mathrm{cm}{ }^{-1}\right)$ & 654 & $250-300$ \\
Demir $(\mathrm{Fe})(\mathrm{ppm})$ & - & $5-20$ \\
Bakır $(\mathrm{Cu})(\mathrm{ppm})$ & 4.21 & $0.2-5$ \\
Çinko $(\mathrm{Zn})(\mathrm{ppm})$ & 8.84 & $2-10$ \\
Mangan $(\mathrm{Mn})(\mathrm{ppm})$ & 9.02 & $0.2-10$ \\
Bor $(\mathrm{B})(\mathrm{ppm})$ & - & $0.5-2$ \\
Alüminyum $(\mathrm{Al})(\mathrm{ppm})$ & 0.06 & $5-20$ \\
Molibden $(\mathrm{Mo})(\mathrm{ppm})$ & - & $0.01-0.05$ \\
Berilyum $(\mathrm{Be})(\mathrm{ppm})$ & - & $0.1-0.5$ \\
Selenyum $(\mathrm{Se})(\mathrm{ppm})$ & - & $0.02-0.02$ \\
Lityum $(\mathrm{Li})(\mathrm{ppm})$ & 2.39 & $2.5-2.5$ \\
Vanadyum $(\mathrm{V})(\mathrm{ppm})$ & 0.68 & $0.1-1$ \\
Nikel $(\mathrm{Ni})(\mathrm{ppm})$ & 3.93 & $0.2-20$ \\
Kobalt $(\mathrm{Co})(\mathrm{ppm})$ & 0.283 & $0.05-5$ \\
Arsenik $(\mathrm{As})(\mathrm{ppm})$ & 0.891 & $0.1-2$ \\
Kurşun $(\mathrm{Pb})(\mathrm{ppm})$ & 0.159 & $5-10$ \\
Kadmiyum $(\mathrm{Cd})(\mathrm{ppm})$ & 0.025 & $0.01-0.05$ \\
Krom $(\mathrm{Cr})(\mathrm{ppm})$ & 1.070 & $0.1-1$ \\
\hline
\end{tabular}

*AATUT 2010

\section{BULGULAR VE TARTIŞMA}

\section{Artan Miktarlarda Atık Su ile Sulanan Karamba'nın Gelişimi}

Araştırmada farklı oranlarda atık su ve saf su (kontrol) ile sulanarak yetiştirilen Karamba bitkisinin çıkış ve ortamdan çekilme gözlemleri, bitki boyu, yaş ağırlık, kuru ağırlık gibi gelişim parametreleri incelendi. Çalışma süresinin ilk 29 günü 4 günde bir olacak şekilde çıkış takibi yapıldı ve ilk biçimden önce 15 adet olan bitki sayısı 10 bitki olacak şekilde seyreltmesi yapıldı. İlk biçimden 
itibaren 8 biçim dönemi baz alınarak incelenen ortamdan çekilme durumu ve bitki çıkış etkinliği üzerine atık su uygulamalarının yapılan varyans analiz sonuçlarına göre bir etkisinin olmadığ belirlendi. Araştırmada incelenen diğer gelişim parametreleri olan bitki boyu için; 8 biçim dönemine ait analiz sonuçları incelendiğinde ikinci ve altıncı biçimlerde farklı sulama uygulamalarının bitki boyu üzerine etkisi önemsiz bulundu. Birinci biçimde uygulamaların etkisi \%5 seviyesinde önemli, diğer biçim dönemlerinde ise sulama uygulamalarının bitki boyuna etkisi istatistiki olarak \%1 düzeyinde önemli olarak belirlendi. En yüksek bitki boyu birinci biçim döneminde $32.4 \mathrm{~cm}$ ile $100 \mathrm{~S}$ uygulamasından elde edilirken, en düşük bitki boyu altıncı biçim döneminde $14.3 \mathrm{~cm}$ ile 75S25A uygulamasından elde edildi (Tablo 2). Araştırma sonuçları farklı konsantrasyonlarda sulama suyu olarak kullanılan atık suyun bitki boyuna etkisinin çalışma süresince oldukça değişken olduğunu gösterdi. En yüksek miktarda uygulanan atık suyun, bitki boyunu genel olarak arttırdığını gösterdi. İlk biçim dönemlerinde daha az belirgin olan bu durum çalışma ilerledikçe daha belirgin olarak görüldü. Saf su ile sulanan kontrol grubu ile en yüksek konsantrasyonda kullanılan atık suyun bitki boyu üzerine etkisi, diğer uygulamalara göre daha benzer oldu. Bhati ve Singh (2003), Eucalyptus camaldulensis Dehnh. üzerinde sadece tekstil atık suyunun bitki büyümesini ve gelişimini azalttı̆̆ belediye atık suyu ve tekstil atık suyunun birlikte kullanımının büyüme ve gelişim artışına neden olduğunu, belediye atık suyu ile sulanan fidelerin en yüksek büyüme ve gelişmeye neden olduğunu bildirmişlerdir. Atık suyun bitki büyümesi ve gelişimi üzerine farklı etkilerinin, kullanılan farklı atık sularda bulunan kimyasal maddelerin özellikle metal iyonların farklılığından kaynaklanabileceğini belirtmişlerdir. Bir başka çalışmada bira fabrikası atık suyunun mısır, ayçiçeği ve susam bitkilerinin bitki boyunu, uygulanan bira fabrikası atık suyunun yüksek konsantrasyonlarının arttırdığ belirlenmiştir (Senthilraja ve ark., 2013).

Tablo 2. Artan miktarlarda atık su ile sulanan Karamba'nın gelişimi

\begin{tabular}{|c|c|c|c|c|c|c|c|c|}
\hline \multirow[b]{2}{*}{ Uygulama } & \multicolumn{8}{|c|}{ Biçim Dönemleri } \\
\hline & 1 & 2 & 3 & 4 & 5 & 6 & 7 & 8 \\
\hline \multicolumn{9}{|c|}{----------------------------------Bitki Boyu------------------------------------ } \\
\hline $100 \mathrm{~S}$ & $32.4 \mathrm{a}$ & 28.5 & $28.1 \mathrm{~b}$ & $24.5 \mathrm{c}$ & $24.6 \mathrm{a}$ & 21.1 & $23.7 \mathrm{a}$ & $25.3 \mathrm{a}$ \\
\hline $75 \mathrm{~S} 25 \mathrm{~A}$ & $30.3 b$ & 27.6 & $26.8 \mathrm{c}$ & $24.5 \mathrm{c}$ & $22.4 b$ & 14.3 & $22.0 \mathrm{bc}$ & $22.8 \mathrm{c}$ \\
\hline $50 \mathrm{~S} 50 \mathrm{~A}$ & $31.5 \mathrm{ab}$ & 27.9 & $29.0 \mathrm{ab}$ & $26.3 b$ & $20.3 c$ & 20.8 & $21.4 \mathrm{c}$ & $24.2 \mathrm{ab}$ \\
\hline $25 \mathrm{~S} 75 \mathrm{~A}$ & $30.7 \mathrm{ab}$ & 26.8 & $29.9 \mathrm{a}$ & $29.6 \mathrm{a}$ & $24 \mathrm{a}$ & 21.3 & $23.0 \mathrm{ab}$ & $24.9 \mathrm{ab}$ \\
\hline F Değeri & $0.048^{*}$ & 0.413 & $0.001^{* *}$ & $0.000^{* *}$ & $0.000^{* *}$ & 0.490 & $0.006^{* *}$ & $0.000^{* *}$ \\
\hline \multicolumn{9}{|c|}{ 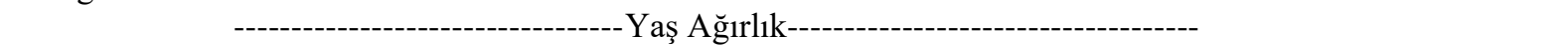 } \\
\hline $100 \mathrm{~S}$ & $6.81 \mathrm{~b}$ & $7.08 \mathrm{a}$ & $4.10 \mathrm{~b}$ & $1.95 \mathrm{~b}$ & $2.68 \mathrm{a}$ & $2.40 \mathrm{a}$ & $2.61 b$ & $2.78 \mathrm{c}$ \\
\hline $75 \mathrm{~S} 25 \mathrm{~A}$ & $7.37 \mathrm{a}$ & $6.66 b$ & $4.35 b$ & $1.98 b$ & $2.13 b$ & $2.08 \mathrm{~b}$ & $2.62 \mathrm{~b}$ & $2.86 \mathrm{c}$ \\
\hline $50 \mathrm{~S} 50 \mathrm{~A}$ & $7.04 \mathrm{ab}$ & $7.09 \mathrm{~b}$ & $4.60 \mathrm{~b}$ & $2.79 \mathrm{a}$ & $2.57 \mathrm{a}$ & $2.43 \mathrm{a}$ & $2.64 \mathrm{ab}$ & $3.28 \mathrm{~b}$ \\
\hline $25 \mathrm{~S} 75 \mathrm{~A}$ & $7.42 \mathrm{a}$ & $7.04 \mathrm{~b}$ & $5.34 \mathrm{a}$ & $2.72 \mathrm{a}$ & $2.69 \mathrm{a}$ & $2.52 \mathrm{a}$ & $2.74 \mathrm{a}$ & $3.52 \mathrm{a}$ \\
\hline F Değeri & $0.046^{*}$ & $0.001^{* *}$ & $0.004^{* *}$ & $0.000^{* *}$ & $0.000^{* *}$ & $0.000^{* *}$ & $0.044^{*}$ & $0.000^{* *}$ \\
\hline \multicolumn{9}{|c|}{--Kuru Ağırlık---- } \\
\hline $100 \mathrm{~S}$ & 0.71 & 0.75 & $0.55 \mathrm{c}$ & $0.34 \mathrm{~b}$ & $0.36 b$ & $0.25 \mathrm{c}$ & $0.36 \mathrm{~b}$ & $0.37 \mathrm{c}$ \\
\hline $75 \mathrm{~S} 25 \mathrm{~A}$ & 0.72 & 0.75 & $0.62 \mathrm{a}$ & $0.37 \mathrm{ab}$ & $0.36 \mathrm{~b}$ & $0.26 b c$ & $0.36 \mathrm{~b}$ & $0.39 \mathrm{c}$ \\
\hline $50 \mathrm{~S} 50 \mathrm{~A}$ & 0.71 & 0.78 & $0.57 b c$ & $0.37 \mathrm{ab}$ & $0.38 b$ & $0.28 \mathrm{ab}$ & $0.39 \mathrm{a}$ & $0.43 b$ \\
\hline $25 \mathrm{~S} 75 \mathrm{~A}$ & 0.74 & 0.79 & $0.60 \mathrm{ab}$ & $0.40 \mathrm{a}$ & $0.44 \mathrm{a}$ & $0.31 \mathrm{a}$ & $0.40 \mathrm{a}$ & $0.49 \mathrm{a}$ \\
\hline F Değeri & 0.630 & 0.302 & $0.01^{* *}$ & $0.042^{*}$ & $0.009^{* *}$ & $0.009^{* *}$ & $0.01^{* *}$ & $0.000^{* *}$ \\
\hline
\end{tabular}

$* \mathrm{P}<0.05$ düzeyinde, $* * \mathrm{P}<0.01$ düzeyinde önemlidir

Araştırmada 8 biçim dönemindeki yaş ağırlığa ait varyans analiz sonuçlarına göre, farklı sulama uygulamalarının bitki yaş ağırlığı üzerine etkisi önemli bulundu. Birinci ve yedinci tartımda uygulamaların etkisi \%5 seviyesinde önemli, diğer biçim dönemlerinde ise sulama uygulamalarının bitki yaş ağırlığına etkisi istatistiki olarak \%1 düzeyinde önemli olarak belirlendi. En yüksek yaş ot ağırlığı birinci biçimden $7.42 \mathrm{~g} \mathrm{saks1}^{-1}$ olarak 25S75A uygulamasından, en düşük yaş ot ağırlığı ise dördüncü biçim döneminde $1.95 \mathrm{~g} \mathrm{saksi}^{-1}$ değeri ile $100 \mathrm{~S}$ uygulaması oluşturmaktadır. Araştırma 
sonuçları farklı oranlarda sulama suyu olarak kullanılan atık su ve saf suyun bitki yaş ağırlığına etkisinin çalışma süresince oldukça değişken olduğunu göstermektedir. En yüksek miktarda uygulanan atık suyun bitki yaş ağırlığını arttırdığı saptandı (Tablo 2). Şahin Dönmez ve ark. (2011), sanayi atıklarının karıştığı su ile sulanan bazı kültür bitkilerinin (mısır, ayçiçeği, fasulye ve yemlik pancar) çimlenme, boy ve ağırlık artı̧̧ının önemli olduğunu saptamışlardır. Angin ve ark. (2005) tarla koşullarında lahana ve patates bitkilerinde atık su sulaması ile ilgili olarak ürün miktarının arttığını bildirmişlerdir. Tahıl üreticiliğinde atık su kullanımı üzerine yapılan bir çalışmada atık suyun verimi arttırdığı saptanmıştır. Sonuç olarak atık suyun sulama açısından olumsuz bir etkisinin olmadığ sulama amaçlı kullanılabileceği bildirilmiştir (Day ve Tucker 1977).

Elde edilen verilere göre farklı sulama uygulamalarının bitki kuru ağırlığı üzerine etkileri altı biçim döneminde önemli, iki biçim döneminde ise önemsiz bulundu. Dördüncü tartımda uygulamaların etkisi \%5 seviyesinde önemli, diğer biçim dönemlerinde ise sulama uygulamalarının bitki kuru ağırlığına etkisi istatistiki olarak \%1 düzeyinde önemli olarak belirlendi. En yüksek kuru ağırlık ikinci biçim döneminde $0.79 \mathrm{~g} \mathrm{saksı}^{-1}$ olarak 25S75A uygulamasından, en düşük kuru ağırlık ise altıncı biçim döneminde $100 \mathrm{~S}$ uygulamasından $0.25 \mathrm{~g} \mathrm{saks1}^{-1}$ olarak elde edildi (Tablo 2). Çalışma sonuçları farklı konsantrasyonlarda sulama suyu olarak kullanılan atık su ve saf suyun (kontrol) bitki kuru ağırlığına etkisinin çalışma süresince oldukça değişken olduğunu göstermektedir. En yüksek miktarda uygulanan atık suyun bitki kuru ağırlığını genel olarak arttırdığı gözlendi. Uygulamalarda genel olarak saf su ile sulanan kontrol grubu en düşük, en yüksek atık su konsantrasyonuyla sulanan uygulamalar en yüksek kuru ağırlık değerleri alındı. Konya bölgesinde mısır bitkisi yetiştiriciliğinde kullanılan atık su etkilerinin incelendiği çalışmada, atık suyun kuru madde miktarını artırdığı, koçan boyu, eni ve boyuna bir etkisi olmadığı belirtilmiştir. Verim ve koçanda dane sayısının atık su ile sulanan uygulamalar ile temiz su kullanılan uygulamalarla aynı olduğu saptanmıştır. Çalışma sonucunda atık suların arıtılarak ve seyreltilerek mısır tarımında kullanılabileceği belirtilmiştir (Çay, 2013).

\section{Artan Miktarlarda Atık Su ile Sulanan Karamba'nın Bazı Element Alımı}

Araştırmada farklı oranlarda atık su ile sulanan Karamba bitkisinde bulunan bazı element konsantrasyonları ve önemlilik değerleri belirlendi. Tablo 3 incelendiğinde uygulamaların Karamba bitkisindeki element içerikleri uygulama sayısı ile doğru orantılı olarak arttığı görüldü. Tabloya göre uygulamaların Karamba bitkisinin tüm element konsantrasyonları üzerine etkisi istatistiki açıdan önemli bulundu $(\mathrm{P}<0.01)$. Buna ek olarak en yüksek atık su oranına sahip uygulamanın (25S75A) element içeriğine etkisi daha fazla oldu. Element konsantrasyonları incelendiğinde en yüksek değerler (25S75A) uygulamasından elde edilmiş olup bunlar; $\mathrm{P}=19823$ ppm, $\mathrm{Ca}=44092$ ppm, Mg=233 07 ppm, $\mathrm{Fe}=0.50 \mathrm{ppm}, \mathrm{Cu}=115.13 \mathrm{ppm}, \mathrm{Zn}=67.47 \mathrm{ppm}, \mathrm{Mn}=504.17 \mathrm{ppm}, \mathrm{Ni}=43.46 \mathrm{ppm}, \mathrm{Li}=3.51 \mathrm{ppm}$, $\mathrm{Al}=0.61 \mathrm{ppm}, \mathrm{Se}=2.47 \mathrm{ppm}, \mathrm{Mo}=0.008 \mathrm{ppm}, \mathrm{V}=2.06 \mathrm{ppm}, \mathrm{Co}=2.78 \mathrm{ppm}, \mathrm{As}=5.79 \mathrm{ppm}, \mathrm{Pb}=0.66$ ppm, $\mathrm{Cr}=14.63$ ppm'dir.. En düşük değerler ise $100 \mathrm{~S}$ uygulamasından elde edilmiş olup bunlar; $\mathrm{P}=175$ $19 \mathrm{ppm}, \mathrm{Ca}=39528 \mathrm{ppm}, \mathrm{Mg}=18895 \mathrm{ppm}, \mathrm{Fe}=0.34 \mathrm{ppm}, \mathrm{Cu}=97.38 \mathrm{ppm}, \mathrm{Zn}=38.67 \mathrm{ppm}$, $\mathrm{Mn}=412.90 \mathrm{ppm}, \mathrm{Ni}=36.22 \mathrm{ppm}, \mathrm{Li}=2.52 \mathrm{ppm}, \mathrm{Al}=0.27 \mathrm{ppm}, \mathrm{Se}=1.84, \mathrm{Mo}=0.006 \mathrm{ppm}, \mathrm{V}=1.30 \mathrm{ppm}$, $\mathrm{Co}=2.29 \mathrm{ppm}, \mathrm{As}=4.34 \mathrm{ppm}, \mathrm{Pb}=0.008, \mathrm{Cd}=0.25 \mathrm{ppm}, \mathrm{Cr}=8.01 \mathrm{ppm}$ 'dir. Genel olarak tüm sonuçlar göz önüne alındığında en yüksek konsantrasyona sahip atık su uygulamalarında besin elementi içeriğinin fazla olduğu, saf su ile sulanan uygulamaların element içeriğinin az olduğu saptandı. Atık su kullanılan suyun kalitesi ve süresine bağlı olarak yarar ve zarar değeri değişmektedir. Yaptığımız çalışmanın sonuçları bize diğer çalışmalarda olduğu gibi atık su uygulama süresinin önemli olduğunu göstermektedir. Sulama süresi uzadıkça ağır metal birikimi de artar (Deveci 2012). 
Tablo 3. Artan miktarlarda atık su ile sulanan Karamba'nın bazı element alımı

\begin{tabular}{|c|c|c|c|c|c|}
\hline \multicolumn{6}{|c|}{ Uygulamalar } \\
\hline Elementler & $100 S$ & 75S25A & 50S50A & 25S75A & F Değeri \\
\hline $\mathrm{P}$ & $17519 b$ & $18994 a$ & $19392 \mathrm{a}$ & $19823 a$ & $0.001^{* *}$ \\
\hline $\mathrm{Ca}$ & $39528 d$ & $40343 c$ & $43235 b$ & $44092 \mathrm{a}$ & $0.000^{* *}$ \\
\hline $\mathrm{Mg}$ & $18895 \mathrm{c}$ & $20378 b$ & $20931 b$ & $23307 a$ & $0.000^{* *}$ \\
\hline $\mathrm{Fe}$ & $0.34 \mathrm{c}$ & $0.36 b c$ & $0.39 b$ & $0.50 \mathrm{a}$ & $0.000^{* *}$ \\
\hline $\mathrm{Cu}$ & $97.38 \mathrm{c}$ & $97.38 \mathrm{c}$ & $112.23 \mathrm{a}$ & $115.13 a$ & $0.000^{* *}$ \\
\hline $\mathrm{Zn}$ & $38.67 \mathrm{c}$ & $58.99 \mathrm{~b}$ & $66.85 a$ & $67.47 \mathrm{a}$ & $0.000^{* *}$ \\
\hline Mn & $412.90 \mathrm{~d}$ & $427.10 \mathrm{c}$ & $463.73 b$ & $504.17 \mathrm{a}$ & $0.000^{* *}$ \\
\hline $\mathrm{Ni}$ & $36.22 \mathrm{c}$ & $41.20 \mathrm{~b}$ & $41.58 \mathrm{~b}$ & $43.46 \mathrm{a}$ & $0.000^{* *}$ \\
\hline $\mathrm{Li}$ & $2.52 \mathrm{c}$ & $2.85 b$ & $3.04 \mathrm{~b}$ & $3.51 \mathrm{a}$ & $0.000^{* *}$ \\
\hline $\mathrm{Al}$ & $0.27 \mathrm{c}$ & $0.44 b$ & $0.45 b$ & $0.61 \mathrm{a}$ & $0.000^{* *}$ \\
\hline $\mathrm{Se}$ & $1.84 \mathrm{c}$ & $1.93 \mathrm{c}$ & $2.22 \mathrm{~b}$ & $2.47 \mathrm{a}$ & $0.000^{* *}$ \\
\hline Mo & $0.006 \mathrm{~b}$ & $0.007 \mathrm{~b}$ & $0.008 \mathrm{a}$ & $0.008 \mathrm{a}$ & $0.006^{* *}$ \\
\hline V & $1.30 \mathrm{c}$ & $1.84 \mathrm{~b}$ & $1.91 \mathrm{~b}$ & $2.06 \mathrm{a}$ & $0.000^{* *}$ \\
\hline Co & $2.29 b$ & $2.36 \mathrm{~b}$ & $2.68 \mathrm{a}$ & $2.78 \mathrm{a}$ & $0.000^{* *}$ \\
\hline As & $4.34 \mathrm{c}$ & $5.33 b$ & $5.79 a$ & $5.79 a$ & $0.000^{* *}$ \\
\hline $\mathrm{Pb}$ & $0.008 \mathrm{~d}$ & $0.460 \mathrm{c}$ & $0.562 b$ & $0.663 \mathrm{a}$ & $0.000^{* *}$ \\
\hline $\mathrm{Cd}$ & $0.25 \mathrm{c}$ & $0.36 \mathrm{~b}$ & $0.42 b$ & $0.49 \mathrm{a}$ & $0.000^{* *}$ \\
\hline $\mathrm{Cr}$ & $8.01 \mathrm{c}$ & $9.71 \mathrm{~b}$ & $13.73 \mathrm{a}$ & $14.63 \mathrm{a}$ & $0.000^{* *}$ \\
\hline
\end{tabular}

** $\mathrm{P}<0.01$ düzeyinde önemlidir

Kalsiyum bitkilerde organik asitlerin etkisini nötralize etmektedir (Bayraktar ve Günay 1996). Fosfor bitki fizyolojisinde enerji kontrolü, kromozom ve genlerin yapı taşı işlevini üstlenmesi ve besinlerin taşınmasında aktif rol oynar. Ayrıca çiçeklenmeyi teşvik etmek ve ürün miktarını arttırmanın yanında saçak kök oluşumu ve bitkide olgunlaşma süresini kısaltmaktadır (Kacar ve Katkat, 2007). Çinko ve bakır gibi ağır metaller bitki gelişmesi ve büyümesi için kofaktör olarak işlev görürler ancak bunların fazlalı̆̆ı toksik etki göstermektedir (Doğan, 2003). Demir çoğu enzimlerin sisteminde prostetik grup olarak işlev gören hemin maddelerinin yapıtaşı olması sebebi ile bitkilerdeki fizyolojik işlevlerde etkin rol alır. Bu elementin bitkilerdeki eksiklik belirtileri başta genç yapraklar olmak üzere yaprak damarları arasında sararma olarak görülmektedir (Jones ve ark., 1991). Bitkilerde Ni fazlalığ 1 toksik etki oluşturur (Eren, 2019). Nikel ağır metallerin arasında, özellikle Zn'den sekiz kat daha fazla toksik etkiye sahip olduğu ve toksisitesinin etkileri sonucunda tarımsal verim de azalmaya neden olduğu bildirilmiştir (Yıldız, 2004; Doğru ve ark., 2021). Mangan bitki gelişimi için gerekli olan mikro besin elementlerinden biridir. Klorofil oluşumu ve enzim reaksiyonlarında aktif rol oynar. Bitkilerdeki eksikliği Mg eksikliği ile benzerlik göstermekte olup özellikle genç yapraklarda sarı noktalar ve damarlar arasında sararmalar olarak görülür (Kıl ve Paksoy 2014). Krom bitki kök gelişimini olumsuz etkiler bu sebepten bitki topraktan yeteri miktarda su ve besin maddesi alamaz ve önemli derecede fotosentetik pigmentlerde bozulma, antioksidant enzimlerin aktivitesi, verim ve kalite düşüşü görülür (Khan ve ark., 2000; Akçin, 2019; Eren, 2020). Kurşun zehir düzeyi bazı bitkilerde oldukça önemli etkiye sahiptir bu yüzden bitkilerdeki kurşun miktarı birikimi insan sağlığı açısından doğrudan bir öneme sahiptir (Daghan ve ark., 2021). Bazı bitkiler bünyesinde bulundurdukları fazla miktardaki kurşunu göstermezler, gayet sağlıklı görünürler ve bu yüzden insanlar tarafından tereddütsüz tüketilir ve tehlike arz ederler (Yıldız, 2004). Gaziantep atık sularının toprak üzerine etkisi ve bazı sebzelerin (patlıcan, domates ve biber) tüketilen kısımlarında demir, kobalt, mangan, çinko ve demir konsantrasyonlarını saptamak ve sağlık risklerini belirlemek için yapılan çalışmada, $\mathrm{Fe}, \mathrm{Cu}, \mathrm{Mn}$, Zn ve Co' in bazı noktalarda sınır değerlerini aştı̆̆ 
belirtilmiştir. Atık su kullanım süresinin uzaması durumunda bitkilerde ve toprakta metal birikiminin artacağı aktarılmıştır. Bitki materyali olarak üçgül bitkisinin kullanıldığı bir çalışmada sulama suyu olarak kullanılan atık suyun sulama sayısına orantılı olarak $\mathrm{Zn}, \mathrm{Cd}, \mathrm{Cu}, \mathrm{Fe}, \mathrm{Cr}, \mathrm{Mn}, \mathrm{Ni}$ ve $\mathrm{Pb}$ konsantrasyonlarının arttığını bildirmişlerdir (Chaudri ve ark. 1992). Yapılan başka bir çalışmada mısır bitkisi yetiştiriciliğinde atık su kullanımı, mısır bitkisinin ağır metal alımı ve toprak kirlenmesinin ürün miktarına etkisi incelenmiştir ve sonuç olarak toprak kirliliğindeki artış miktarı ile orantılı olarak bitki bünyesinde $\mathrm{Cu}, \mathrm{Cd}, \mathrm{Pb}$ ve $\mathrm{Zn}$ içeriğinin de arttığı, meydana gelen bu artışın kurşun ve bakıra göre çinko ve kadmiyumda daha belirgin olduğu bildirilmiştir (Metz ve Wilke. 1992).

\section{Artan Miktarlarda Atık Su ile Sulanan Karamba'nın Hasadı Sonrası Toprağın Bazı Özellikleri}

Farklı konsantrasyonlarda atık su ile sulanan Karamba bitkisinin hasadından sonra, hasat sonu toprağın bazı özellikleri incelendi ve Tablo 4'te sunuldu. Elde edilen sonuçlara göre toprağın pH, EC değerleri ile $\mathrm{Zn}, \mathrm{Mn}, \mathrm{Al}, \mathrm{Pb}$ ve $\mathrm{Cr}$ konsantrasyonları \%1, B, Ni, Co, As ve Cd konsantrasyonları \%5 seviyesinde önemli bulundu.

Tablo 4. Denemede kullanılan toprağın hasat öncesi ve hasat sonrası bazı özellikleri

\begin{tabular}{|c|c|c|c|c|c|c|}
\hline \multirow[t]{2}{*}{ Özellikler } & \multirow[t]{2}{*}{ Hasat öncesi } & \multicolumn{3}{|c|}{ Hasat sonras1 } & & \multirow{2}{*}{$\begin{array}{c}\text { F } \\
\text { Değeri }\end{array}$} \\
\hline & & $100 \mathrm{~S}$ & $75 \mathrm{~S} 25 \mathrm{~A}$ & $50 \mathrm{~S} 50 \mathrm{~A}$ & $25 \mathrm{~S} 75 \mathrm{~A}$ & \\
\hline Tekstür sınıfı & Tinlı & & & & & \\
\hline $\operatorname{Kum}(\%)$ & 20 & & & & & \\
\hline Kil $(\%)$ & 46 & & & & & \\
\hline Silt $(\%)$ & 34 & & & & & \\
\hline $\mathrm{pH}$ & 8.26 & $8.436 \mathrm{a}$ & $8.316 \mathrm{~b}$ & $8.106 \mathrm{c}$ & $8.090 \mathrm{c}$ & $0.000^{* *}$ \\
\hline $\mathrm{EC}\left(\mu \mathrm{mhos} \mathrm{cm}^{-1}\right)$ & 346.2 & $218.4 d$ & $357.8 \mathrm{c}$ & $453.2 b$ & $523.0 \mathrm{a}$ & $0.000^{* *}$ \\
\hline Organik Madde (\%) & 1.57 & 1.060 & 1.616 & 1.626 & 1.640 & 0.387 \\
\hline $\mathrm{Fe}(\mathrm{ppm})$ & 102.2 & 96.9 & 93.8 & 96.2 & 97.1 & 0.359 \\
\hline $\mathrm{Cu}(\mathrm{ppm})$ & 0.113 & 0.114 & 0.113 & 0.113 & 0.108 & 0.255 \\
\hline $\mathrm{Zn}(\mathrm{ppm})$ & 0.213 & $0.179 \mathrm{c}$ & $0.192 b$ & $0.206 \mathrm{a}$ & $0.204 \mathrm{a}$ & $0.002^{* *}$ \\
\hline $\mathrm{Mn}(\mathrm{ppm})$ & 2.471 & $2.177 \mathrm{~d}$ & $2.201 \mathrm{c}$ & $2.260 \mathrm{~b}$ & $2.287 \mathrm{a}$ & $0.000^{* *}$ \\
\hline $\mathrm{B}(\mathrm{ppm})$ & 0.665 & $0.652 \mathrm{a}$ & $0.643 \mathrm{cb}$ & $0.648 \mathrm{ab}$ & $0.637 \mathrm{c}$ & $0.015^{*}$ \\
\hline $\mathrm{Al}(\mathrm{ppm})$ & 308.7 & $41.32 \mathrm{~d}$ & $56.02 \mathrm{c}$ & $68.32 b$ & $78.71 \mathrm{a}$ & $0.000^{* *}$ \\
\hline Mo (ppm) & - & - & - & - & - & \\
\hline $\mathrm{Be}(\mathrm{ppm})$ & 0.0009 & 0.001 & 0.001 & 0.003 & 0.003 & 0.616 \\
\hline $\mathrm{Se}(\mathrm{ppm})$ & - & - & - & - & - & \\
\hline $\mathrm{V}(\mathrm{ppm})$ & - & - & - & - & - & \\
\hline $\mathrm{Ni}(\mathrm{ppm})$ & 0.448 & $0.382 b$ & $0.402 \mathrm{a}$ & $0.388 b$ & $0.386 b$ & $0.032^{*}$ \\
\hline Co (ppm) & 0.071 & $0.061 b$ & $0.063 \mathrm{a}$ & $0.063 \mathrm{a}$ & $0.064 \mathrm{a}$ & $0.045^{*}$ \\
\hline As (ppm) & 0.116 & $0.100 \mathrm{~b}$ & $0.104 \mathrm{ab}$ & $0.112 \mathrm{a}$ & $0.108 \mathrm{ab}$ & $0.037^{*}$ \\
\hline $\mathrm{Pb}(\mathrm{ppm})$ & 0.026 & $0.232 b$ & $0.238 \mathrm{a}$ & $0.226 \mathrm{c}$ & $0.225 c$ & $0.003^{* *}$ \\
\hline $\mathrm{Cd}$ (ppm) & 0.0006 & $0.0004 \mathrm{a}$ & $0.0003 b$ & $0.0004 \mathrm{a}$ & $0.0003 b$ & $0.055^{*}$ \\
\hline $\mathrm{Cr}(\mathrm{ppm})$ & 0.377 & $0.349 b$ & $0.343 \mathrm{c}$ & $0.356 \mathrm{a}$ & $0.354 \mathrm{ab}$ & $0.003^{* *}$ \\
\hline
\end{tabular}

* $\mathrm{P}<0.05$ düzeyinde, $* * \mathrm{P}<0.01$ düzeyinde önemlidir

Hasat sonrası toprakların bazı element konsantrasyonlarına bakıldığında atık su kullanımının kontrol parsellerine göre topraktaki $\mathrm{Fe}, \mathrm{Cu}$ ve $\mathrm{B}$ konsantrasyonunu düşürdüğü, $\mathrm{Zn}, \mathrm{Mn}, \mathrm{Al}, \mathrm{Ni}, \mathrm{Co}, \mathrm{As}$, $\mathrm{Pb}, \mathrm{Cd}$ ve Cr konsantrasyonlarını bir miktar arttırdığı, Mo, Se ve Be konsantrasyonlarını etkilemediği belirlendi. Artan konsantrasyonlarda sulama suyu olarak kullanılan atık suyun topraktaki pH düzeyini deneme süresi sonunda kontrol parsellerine göre bir miktar düşürdügü, toprak EC ve organik madde içeriğini arttırdığı gözlemlenmiştir. Özellikle pH değeri yüksek topraklarda bu durum bitki yetiştiriciliği açısından oldukça önemlidir. Yüksek pH değeri bitkilerin toprakta bulunan bazı besin 
elementlerinden yararlanma derecesini düşürmektedir. Sulama suyu olarak kullanılan atık suyun $\mathrm{pH}$ durumuna göre toprağın $\mathrm{pH}$ değerini düşürdüğü, yükselttiği veya etkilemediği bilinmektedir (Shahalam ve_ark., 1998; Uyanöz, 2000). Atık suların tarımda kullanımını sınırlayan faktörlerin en önemlilerinde biri de toprak tuzluluğunun artmasına neden olmasıdır. (FAO, 2003). Aşık ve Katkat (2005), atık suların sulama suyu olarak kullanılmasının alternatif olarak değerlendirilebileceği, ancak bu suların kullanılması durumunda toprakta tuz birikimi sorununun ortaya çıkabileceğini ve tuza hassas bitkilerin yetiştiriciliğinde sorunlar yaşanabileceğini belirtmişlerdir (Akın ve Aşık 2018).

\section{SONUÇ}

$\mathrm{Bu}$ çalışmada Van /Edremit İlçesi ileri biyolojik arıtma tesisi atık suyu ile sulamanın Karamba bitkisinin gelişimi ile içerdiği bazı elementlere etkisi ve uygulamalar sonucunda hasat sonrası topraklarda biriken bazı elementlerin belirlenmesi amaçlandı.

Artan konsantrasyonlarda uygulanan atık suyun bitkinin çıkışını ve ortamdan çekilmesine etkisinin olmadığı, buna karşılık en yüksek konsantrasyonla sulamanın bitki boyunu arttırdığı belirlendi. Uygulamaların yaş ot miktarına etkisi önemli bulunmuş olup, özellikle çalışmanın ilerleyen dönemlerinde yüksek konsantrasyonlarla atık su sulamasının yaş ot miktarını arttırdığı belirlenmiştir. Uygulanan atı su sulaması sonucunda kuru ot miktarı da etkilendi ve artan atı su konsantrasyonlarına bağlı olarak alınan kuru ot miktarları da arttı. Özellikle dördüncü biçimden sonra bu fark daha da belirginleşmiş olup sekizinci biçimde en yüksek kuru ot 25S75A uygulamasından belirlendi. Bitkinin element konsantrasyonları da artan atık su konsantrasyonlarına bağlı olarak arttı. $\mathrm{Bu}$ artışlar kısa vadede bitki yetiştiriciliğinde sınır değerlere ulaşmamakla birlikte daha uzun vadeli yetiştiricilikte ifade edebileceği anlam, bu konu üzerinde çalışılması gerektiğini düşündürmektedir. Özellikle nikel, kurşun, kadmiyum, krom gibi element konsantrasyonları artışı dikkatle incelenmesi gerekir. Uygulamalar sonrası alınan toprak örneklerinde $\mathrm{pH}$ değeri düştü ancak EC değerinde artış saptandı. EC değerinin artışı sınır değerlerin altında olmakla birlikte uzun süreli atık su ile sulamalarda yine bu durum dikkate alınmalıdır. Toprak element içeriklerinde çalışma süresi sonunda çok büyük farklılıklar belirlenmedi.

Sonuç olarak yaşamın devamlılığı açısından çok önemli olan su kaynaklarının giderek azalması ilerleyen dönemde atık suların yeniden kullanılmasını kaçınılmaz kılmaktadır. Bu çalışma ile Van İli kanalizasyon çıkış suyunun tarımda kullanılma olanaklarına ön bir çalışma ile 1şı tutulmaya çalışılmıştır. Bu konuda farklı bitki gruplarıyla daha uzun süreli çalışmalara ihtiyaç bulunmaktadır.

\section{TEŞEKKÜR}

Bu tez çalışmasının yürütülmesine FYL-2018-7399 No'lu proje kapsamında destekte bulunan Van Yüzüncü Yıl Üniversitesi Bilimsel Araştırmalar ve Proje Başkanlığına teşekkür ederiz.

\section{Çıkar Çatışması}

Yazarlar arasında herhangi bir çıkar çatışması bulunmamaktadır.

\section{Yazar Katkısı}

Yazarlar denemenin yürütülmesi ve yazım aşamasında eşit oranda katkı sunmuşlardır.

\section{KAYNAKLAR}

AATTUT, 2010. Atıksu Arıtma Tesisi Teknik Usuller Tebliği, T.C. Resmi Gazete, 27527, 20.03.2010. Akın HF, Aşık BB, 2018. Nilüfer çayı ve farklı arıtma tesisleri atıksularının, toprak özellikleri ve bitki gelişimi üzerine etkilerinin belirlenmesi. Uludağ Üniversitesi Ziraat Fakültesi Dergisi, 32(1):1530 . 
Amaral GA, Kozloski GV, Santos AB, Castagnino DS, Fluck AC, Farenzena R, Alves TP, Mesquita $\mathrm{R}$, 2011. Metabolizable protein and energy supply in lambs fed annual ryegrass (Lolium multiflorum Lam.) supplemented with sources of protein and energy. Journal of Agricultural Sciences, 149:519-527.

Angin İ, Yağanoğlu AV, Turan M, 2005. Effects of Long-Term Wastewater İrrigation on Soil Properties. Journal of Sustainable Agriculture, 26 (3): 31-42.

Anonim, 2018. Devlet Su İşleri Genel Müdürlüğü 2015 yılı faaliyet raporu.

Anonim, 2018. Karamba Yem Bitkisi. http://ulusoyseed.com.tr/urunler/yem-bitkileri/caramba-mix. (Erişim tarihi: 15.02.2021.)

Aşık B, Katkat AV, 2005. Gıda Sanayii Arıtma Tesisi Atık Suyunun Sulama Suyu Olarak Kullanım Olanağı. Uludağ Üniversitesi Ziraat Fakültesi Dergisi, 19 (2): 23-31.

Baldinger L, Baumung R, Zollitsch W, Knaus WF, 2011. Italian ryegrass silage in winter feding of organic dairy cows: forage intake, milk yield and composition. Journal of the Science of Food and Agriculture, 91:435-442.

Bayraktar K, Günay B, 1996. Sebze Yetiştirme. Ege Üniversitesi Ziraat Fakültesi Yayınları No: 245, İzmir. 360.

Bernard JK, West JW, Trammell DS, 2002. Effect of Replacing Corn Silage With Annual Ryegrass Silage on Nutrient Digestibility, İntake, And Milk Yield For Lactating Dairy Cows. Journal of Dairy Science, 85: 2277-2282.

Bhati M, Singh G, 2003. Growth and Mineral Accumulation in Eucalyptus Camaldulensis Seedlings İrigated With Mixed İndustrial Effluents. Bioresource Technology, 88: 221 - 228.

Bouyoucos GJ, 1951. A Recabliration of the Hidrometer for Marking Mechanical Analysis of Soil. Agronomy Journal, 43: 434-437.

Catanese F, Distel RA, Arzadun M, 2009. Preferences of Lambs Offered Italian Ryegrass (Lolium multiflorum L.) and Barley (Hordeum vulgare L.) Herbage as Choices. Grass and Forage Science, 64: 304-309.

Chaudri AM, McGrath, S.P., Giller, K.E., 1992. Metal Tolerance of Isolates of Rhizobium Leguminasosarum Biovar Trifoli from Soil Contaminated By Past Applications of Sewage Sludge. Soil Biology and Biochemistry, 24(2): 83-85.

Cooke KM, Bernard JK, West JW, 2008. Performance of dairy cows fed annual ryegrass silage and corn silage with steam-flaked or ground corn. Journal of Dairy Science. 91:2417-2422.

Çay Ş, 2013. Konya Kentsel Atık Suların Tarımsal Sulamada Kullanılması ve Misır Bitkisi Yetiştiriciliğine Etkileri. Çukurova Üniversitesi Fen Bilimleri Enstitüsü, Doktora Tezi, (Basılmamış).

Çetinkaya AV, 2019. Sütotu (Ryegrass-lolium multiflorum lam.) ve Yonca (Alfalfa-medicago sativa L.)'nın Besin Madde İçerikleri ve Sindirilebilirliklerinin Karşılaştırılması. Yüksek Lisans Tezi, SAğlık Bilimleri Enstitüsü, Kırıkkale Üniversitesi, 47 s.

Daghan H, Uygur V, Eren A, 2021. Lead Phytoremediation Potential of Wild Type and Transgenic Tobacco Plants. ISPEC Journal of Agricultural Sciences, 5(1): 168-182.

Day AD, Tucker TC, 1977. Effects of Treated Wastewater on Growth, Fibre, Protein and Amino Acid Content of Sorghum Grains. Journal of Environmental Quality, 6(3): 325-327.

Deveci T, 2012. Gaziantep' te Atık Sulardan Etkilenen Toprak ve Bitkilerde Eser Element (Cu, Co, $\mathrm{Mn}$ ve $\mathrm{Zn}$ ) ve Fe Konsantrasyonlarının ICP-MS ile Tayini. Kilis 7 Aralık Üniversitesi, Fen Bilimleri Enstitüsü, Yüksek Lisans Tezi (Basılmamış).

Doğan M, 2003. Şanlıurfa'da Karakoyun Deresi Atık Suları ile Sulanan Soğanda (Allium Cepa L.) 
Toksik Element Birikimi Üzerine Bir Araştırma. Ekoloji Çevre Dergisi, 12(48): 1-3.

Doğru A, Altundağ H, Dündar MŞ, 2021. Gelişmiş Bitkilerde Nikel Elementinin Fizyolojik Fonksiyonları ve Nikel Toksisitesi. Frrat Üniversitesi Fen Bilimleri Dergisi, 33(1): 1-19.

DSİ, 2018. Tarımda Toprak ve Suyun Sürdürülebilir Kullanımı, Özel İhtisas Komisyonu Raporu, Ankara.

Eren A, 2019. Phytoextraction of Nickel Contaminated Soil with Citric Acid and Humic Acid Treatments using Rosemary (Rosmarinus officinalis) Plant. International Journal of Environmental Sciences and Natural Resources, 19(4):1-6.

Eren A, 2020. Humik Asit ve Sitrik Asit Uygulamalarının Krom ile Kirlenmiş Topraklarda Biberiye (Rosmarinus Officinalis) Bitkisinin Fitoremediasyonu. Ejons International Journal on Mathematics, Engineerıng-Natural Sciences, 14: 387-395.

FAO 2003. The State of Food Insecurity in the World. Food and Agriculture Organization of the United Nations Viale delle Terme di Caracalla, 00100 Rome, Italy.

Gemalmaz E, Talay B, 2016. Alternatif Kaba Yem Kaynakları. Lalahan Hayvancılık Araştırma Enstitüsü Dergisi, 56(2): 63-69.

Jones JB, Wolf B, Mills HA, 1991. Plant Analysis Handbok. Micro-Macro Publushing, Inc., USA. 213.

Kacar B, İnal A, 2008. Bitki Analizleri. Nobel Yayın No:1241, Fen Bilimleri. 63.

Kacar B, Katkat AV, 2007. Gübreler ve Gübreleme Tekniği. Nobel Yayınları No: 119.

Kesiktaş M, 2010. Karaman'da Farklı Ekim Zamanları ve Azotlu Gübre Dozu Uygulamalarının İtalyan Çiminin (Lolium multiflorum Westerwoldicum Caramba) Yem Verimine Etkisi. Çukurova Üniversitesi, Fen Bilimleri Enstititüsü, Yüksek Lisans Tezi, (Basılmamış).

Khan AG, Kuek C, Chaudhry TM, Khoo CS, Hayes WJ, 2000. Role of Plants, Mycorrhizae and Phytochelators in Heavy Metal Contaminated Land Remediation. Chemosphere, 41: 197-207.

K1l R, Paksoy M, 2014. Organik ve İnorganik Gübrelerin Karnabaharda Bitki Gelişimi ve Verime Etkisi. 10. Sebze Tarımı Sempozyumu. 2- 4 Eylül, Tekirdağ.

Kuşvuran A, Tansı V, 2005. Çukurova Koşullarında Farklı Biçim Sayısı ve Azot Dozunun Tek Yıllık Çimin (Lolium multiflorum cv. Caramba) Ot ve Tohum Verimine Etkisinin Saptanması. Türkiye VI. Tarla Bitkileri Kongresi 5- 9 Eylül, Antalya.

Lenuweit U, Gharadjedaghi B, 2002. Biologische Basisdaten zu Lolium perene, Lolium multiflorum, Festuca pratensis und Trifolium repens. Gesellschaft für Freilandökologie und Naturschutzplanung mbH, Bayreuth, Texte des Umweltbundesamtes, 7 - 8.

Mccormick ME, Cuomo GJ, Blouin DC, 1998. Annual ryegrass stored as balage, haylage or hay for lactating dairy cows. Journal of Production Agriculture, 11: 293-300.

Mccormick ME, Morgan EB, Brown TF, Saxton AM, 1990. Relationships Between Silage Digestibility and Milk Production Among Holstein cows. In: Proc. Forage Grassland Conferance American Forage Grassland Council, Belleville, VA, USA. 60-64.

Mclean EO, 1982. Soil pH and Lime Requirement. Methods of Soil Analysis, Part 2. Chemical and Microbiological Properties. American Society of Agronomy Soil Science Society of America, Madison, 9: 199-223.

Metz R, Wilke BM, 1992. Influence of Soil Pollution in Fields İrigated With Sawage on Growth, Yield and Heavy Metal Uptake of Maize in a Pot Trial. Wissenschaftliche Zeitschrift der Humboldt Universitat zu Berlin. Reihe Agrarwisserr, 41(3): 29-33. 
Miller LA, Moorby JM, Davies DR, Humphreys MO, Scollan ND, MacRae JC, Theodorou MK, 2001. Increased Concentration of Water-Soluble Carbohydrate in Perennial Ryegrass (Lolium perenne L.): Milk Production from Latelactation Dairy Cows. Grass Forage Science, 56: 383394.

Nelson RE, 1982. Carbonate and Gypsum. Methods of Soil Analysis, Part 2. Chemical and Microbiological Properties, ed: a.l. page. American Society of Agronomy, 9:181-196.

Özkul H, Kırkpınar F, Tan K. 2012. Ruminant beslemede karamba (Lolium multiflorum cv. Caramba) otunun kullanımı. Derleme, Hayvansal Üretim, 53(1): 21-26.

Pescod MB, 1992. Wastewater Treatment and Use in Agriculture. Irrigation and Drainage Paper, No. 47, FAO, Rome, 125.

Polat A, 2013. Su Kaynaklarının Sürdürülebilirliği İçin Arıtılan Atıksuların Yeniden Kullanımı. Türk Bilimsel Derlemeler Dergisi, 6(1): 58-62.

Richards LA, 1954. Diagnosis and Improvement of Saline and Alkali Soils USA Handbook No. 60, Oxford and IBH Publishing Co. Calcutta, 160.

Senthilraja K, Jothimani P, Rajannan G, 2013. Effect of Brewery Wastewater on Growth and Physiological Changes in Maize, Sunflower and Sesame Crops. Ijlser, 1(1): 36-42.

Serin Y, Tan M, 2001. Yem Bitkileri Kültürüne Giriş. Atatürk Üniversitesi, Ziraat Fakültesi. Yayın No: 206, Erzurum. 217.

Shahalam A, Abuzahra BM, Jaradat A, 1998. Wastewater İrigation Effect on Soil, Crop and Environmental Pilot Scale Study at Irbid, Jordan. Water, Air, and Soil Pollution, 106(3-4): 425445.

Soya H, Avcıŏglu R, Geren H, 2004. Yem Bitkileri. Hasad Yayıncılık Ltd. Şti. PK. 212, Kadıköyİstanbul. 223.

Şahin Dönmez M, Ceylan Ö, Konuk M, 2011. Dokuz Sele Çayı' na (Ulubey - Uşak) Bırakılan Sanayi Atıklarının Bazı Kültür Bitkilerinin Çimlenme ve Büyümeleri Üzerine Etkileri. Biyoloji Bilimleri Araştırma Dergisi, 4(2): 157-163.

TÜİK(2019).https://biruni.tuik.gov.tr/mes/?kn=92\&locale=tr . (01.12.2020).

Uyanöz R, 2000. Konya'da Sulama Suyu Olarak Kullanılan Atıksuların Tarım Topraklarının Bazı Fiziksel, Kimyasal ve Biyolojik Özelliklerine Etkileri. Selçuk Üniversitesi, Doktora Tezi, (Basılmamış).

Van Niekerk WA, Hassen A, Coertze RJ, 2008. Diet Quality, Intake and Growth Performance of South African Mutton Merino sheep on Triticum $\times$ Secale and Lolium multiflorum pastures at different grazing pressures. Tropical Grassland, 42:54-59.

VASKİ, 2018. Van Su ve Kanalizasyon İdaresi Genel Müdürlüğü.

Yıldız S, 2004. Konya Ana Tahliye Kanalında Ağır Metal Kirliliğinin ICP-AES Tekniği ile İncelenmesi. Selçuk Üniversitesi, Fen Bilimleri Enstitüsü, Yüksek Lisans Tezi, (Basılmamış). 151.

Yolcu H, Tan M, 2008. Ülkemiz Yem Bitkileri Tarımına Genel Bir Bakış. Ankara Üniversitesi Ziraat Fakültesi Tarım Bilimleri Dergisi, 14 (3): 303-312.

Zaman M.S, Mir Z, Mir PS, El-Meadawya A, McAllister TA, Cheng KJ, Zobell D, Mathison GW, 2002. Performance and Carcass Characteristics of Beef Cattle Fed Diets Containing Silage from İntercropped Barley and Annual Ryegrass. Animal Feed Science and Technology, 99: 1-11. 